\title{
Analysis of Motorcycle Parking Charges in the Klaten City Shopping Area
}

\author{
Septiyanti Ristuningsih* and Romi Bhakti Hartarto
}

\section{DPEN}

\section{AFFILIATION:}

Department of Economics, Faculty of Economics and Business, Unive rsitas Muhammadiyah Yogya karta, Special Regional of Yogya karta, Indonesia

\section{*CORRESPONDENCE:}

septiyanti.ristuningsih@gmail.com

\section{THIS ARTICLE IS AVALILABLE IN:}

http://journal.umy.ac.id/index. php/jerss

DOI: 10.18196/jers s.v5i1.10940

\section{CITATION:}

Ristuningsih, S., \& Ha rtarto, R.B. (2021). Analysis of motorcycle parking charges in the Klaten city shopping area. Journal of Economics Research and Social Sciences, 5(1), 13-26.

\begin{abstract}
The implementation of regional a utonomy adheres to the principle that financial sources originating from Regional Original Income (PAD) are more critical than sources outside PAD. Therefore, adequate financial sources are needed to finance the implementation of regional autonomy, one of which is through regional levies. One of the sources of revenue from sizeable regional user fees is parking fees. This sector is one of the essential sources of revenue because it always develops and develops an area (city). If it is appropriately managed, it can supportPAD. This study aims to determine the number of potential parking fees in the shopping area of Klaten City and find strategies to optimize the potential for parking fees through surveys, observations, mathematical calculations, and comparative techniques to obtain an overview of the potential and conditions of the parking location. The results obtained include: 1 ) The potential for parking fees is currently IDR 2,090,880,000.002) The efforts of local governments in increasing parking fees are not optimal 3) Strategies that can be used to increase parking fees can be done by establishing new regulations so that new potential the resulting amount will be IDR 2,471,040,000.00. Based on these findings, this research is expected to be a reference for the Klaten City government in optimizing the potential for parking fees; Besides, it is hoped that this research can enrich previous scientific findings related to parking fees. Keywords: Retribution; Local Revenue; Regional Autonomy; Mathematical Techniques; Comparative Techniques
\end{abstract}

JEL Classification: R48, R52

\section{Introduction}

One of the demands for reform in the context of governance is regional autonomy. Regional autonomy aims to manifest the delegation of authority and responsibility in which each region is given the authority to manage its region independently. Regional autonomy itself was officially enacted in Indonesia on January 1, 2001. With the official regional autonomy system, regional governments can regulate their regions according to their individual needs. This decision is expected to encourage local governments to pay more attention to their regions to be more advanced. To achieve progress, the role of local government is significant in understanding how much funds are needed to finance regional development. Therefore, local government and community participation must estimate the resources needed to build and develop the regional economy (Arsyad, 1999).

In implementing autonomy, a region is very dependent on the role of various financial sources to finance its autonomy administration. 
Financial sources are intended to be the primary support in financing various development activities. This financial availability will later be used to finance various kinds of regional expenditure for optimal development. The revenue and expenditure budget in regional development activities can be seen from the Regional Revenue and Expenditure Budget (APBD) balance. As a policy instrument, the APBD occupies a central position to develop the capacity and effectiveness of local governments. Local revenue sources are used to support the APBD.

Based on Law No. 32 of 2004 concerning the financial balance between the central govemment and regional governments, it is stated that local taxes and levies are one of the essential sources of income for financing the implementation of the independent regional government. Taxes and fees are among the PAD revenues that every region relies on as a contributor to revenue. It seems that regional taxes and levies have not been optimal by the regions as a source of decentralization financing. Many problems occur in the regions related to the extraction and increase of PAD. It is primarily due to the relatively low base of local taxes and levies. Its relatively small role in total regional revenue, the low administrative capacity of the collection in the regions, and weak financial planning and supervision capabilities. Therefore, it is necessary to increase the contribution of PAD from the regional retribution sector.

One of the levies that contribute to the value of PAD is parking fees. A parking levy is a payment by an individual or entity for the parking services provided by him. The local govemment carries out the ownership and management of parking fees as one source of PAD that comes from the community. The management of parking fees is carried out by the Regional Revenue Service by statutory regulations.

Klaten Regency, as an autonomous region, has PAD, one of the sources of local retribution, which should make an enormous enough contribution. As a regional financing source, Klaten Regency's Local Own Revenue (PAD) still does not play much of a role. The total local revenue of Klaten Regency in 2015 increased by 190 billion rupiahs or grew by an average of $28 \%$ each year. Besides, the details of each component's increase include regional taxes of 68 billion rupiahs, regional levies of 21 billion rupiahs, management of regional assets of 7 billion rupiahs, and other revenues of 93 billion rupiahs. Until 2016, local fees only contributed $12.7 \%$ of the total PAD as a whole. Given that Klaten Regency is located in a strategic area on Jalan Pemuda as the intersection of road users between the City of Surakarta and the Special Region of Yogyakarta, which has the capital and shopping center of Klaten City, the potential is enormous to contribute to increasing PAD.

Klaten City Center is a center of activity and a shopping center that is never empty of visitors. Apart from being a center for Klaten residents' activities, Klaten City Center is also used as a stopover area for tourists. This area is a center of activity that is never empty of visitors and has parking lots, both particular parking lots and parking lots on the side of public roads, the management of which is in the Klaten Regional Government's hands. It, of course, has the potential to collect regional levies. Therefore, 
the government's role is urgently needed to explore and optimize all the potential it has to encourage the success of development in the Klaten Regency.

One of the potential sources that can be explored is retribution for shopping areas, especially parking fees. Currently, the regular tariff for parking fees in the Klaten City shopping area is IDR 1,000.00, which is constitutionally in ratification from 2016 which will then be set in 2017. If it is based on the new rate, parking attendants only provide an IDR (Rp) deposit, equivalent to 300 tickets for 300 vehicles as in the previous use ticket. In fact, during the 12 hours, the number of vehicles parked was more than 300 vehicles. Thus, the Klaten Regional Government can receive revenues of more than IDR $300,000.00$ per day based on the new tariff. This fact is confirmed by Purnamasari and Ngumar (2015) that parking can be used as a potential source of regional income.

There is a problem with local government revenue through parking fees, which is still relevant to be optimized by updating parking systems and regulations from the phenomenon. If this goes well and correctly, PAD will be increased through parking fees. Therefore, the government must review how much potential parking fees can be extracted and developed so that it can be seen how much the target can be achieved from this potential. In the end, all the potential parking fees that exist can provide optimal continuity to PAD. Based on this background, this study intends to calculate how much potential regional revenue from motorcycle parking fees in the shopping area of Klaten City. Also, this study aims to find solutions and dete rmine the right strategy in optimizing motorcycle parking fees.

Butarbutar (2014) analyzed the role of parking tax in increasing PAD in Tomohon City. By using the descriptive method, the results obtained show that the parking tax contributes to local taxes and al ways increases each year. The amount of contribution given is $0.80 \%$ of the total PAD until November 2014. Meanwhile, Putri's research (2016) intends to determine how much contribution, growth, and effectiveness of parking fees in Malang Regency 2010-2014 and how the forecasting realization of parking fees for 2015-2019. The results of his research stated that the growth and contribution of parking fees to PAD fluctuated. However, the level of effectiveness of parking fees on PAD is classified as an adequate criterion. The trend of predicting the realization of parking fees in 20152019 continues to increase.

Kesek's research (2013) analyzes the level of effectiveness and contribution of parking tax to PAD in Manado City. The method used in this rese arch is descriptive qualitative by analyzing target data, data on realization and contribution of parking tax in 2009-2012. The results showed that parking taxes' target and realization increased with varying levels of effectiveness and contribution sizes. The highest level of effectiveness occurred in 2012 at $155.89 \%$, and the lowest was in 2009 at $69.14 \%$. The contribution of user fees in the city of Manado is still low because it is only 1.65\%, but during 2009-2012 it continues to increase every year. 


\section{Research Method}

This research uses a qualitative descriptive research method because the researcher starts from the data, then uses existing theories as explanatory material, and ends with a descriptive study of the data set out in the form of a report or description. The research object in the preparation of this thesis was carried out in the shopping area of Klaten City, namely the Laris Shop Parking, Semar Shop Parking, Mas Semar Shop Pakir, and Sami Laris Shop Parking. The research object is taken into account because this location is the densest parking location compared to other locations in the Klaten City shopping area.

The sampling technique is carried out randomly, namely by giving a number according to the number of lots in the four locations, and the researcher will take data randomly for two hours in two-time shifts, namely shift one at 08.00-14.00 and shift two at 14.0020.00. The data were collected through direct observation of parking locations, which were then analyzed with several analytical tools to answer existing problems, namely qualitative descriptive, mathematical techniques, comparative techniques, and SWOT analysis.

In this study, qualitative descriptive analysis was used to describe the people's social conditions in the parking area of the Klaten City shopping area. Meanwhile, mathematical techniques are used to calculate total turnover and local revenue from motorcycle parking fees in the area used as the research object. The potential daily income for motorcycle parking fees is calculated using the equation:

$$
P R P k h=V_{k h} \times \mathrm{TRPk} \times \mathrm{BHk}
$$

Where

PRPkh = Potential daily vehicle parking fees (IDR);

$V k h \quad=$ Average volume of vehicles per day (units);

TRPk = Vehicle parking fee (IDR);

$B H k$ = Share the revenue sharing from vehicle parking fees between the Klaten Regional Government and parking managers according to the PERDA.

Meanwhile, the potential annual revenue from motorcycle parking fees is calculated using the equation:

$$
P R P k t=P R P_{k t} \times 360
$$

Where:

PRPkt = Potential annual vehicle parking fees (IDR)

Furthermore, a comparative technique is used to compare the potential parking fees to actual local governments. This comparison is expected to provide an overview of whether the parking fee system has been running effectively or not in contributing to local government revenue. 
SWOT analysis is an analysis tool used to obtain an overview of a problem based on internal factors (opportunities and threats) and external factors (strengths and weaknesses). SWOT analysis only describes the conditions that occur on a variable, not as a problem solver. The image obtained can be used to find a strategy to be carried out on the variables. The tool used to develop a SWOT analysis strategy is the SWOT matrix. This matrix aims to obtain four sets of possible strategies. In this study, SWOT analysis was used to obtain an overview of the strengths, weaknesses, opportunities, and threats to the management of parking fees.

Table 1 SWOT matrix

\begin{tabular}{|c|c|c|}
\hline $\begin{array}{ll}\text { Internal factors Externai } & \text { Factor } \\
\end{array}$ & Strengths (S) & Weakness (W) \\
\hline Opportunities (O) & SO strategy & WO strategy \\
\hline Threats $(\mathrm{T})$ & ST strategy & WT strategy \\
\hline
\end{tabular}

The strategy made based on the SWOT matrix in Table 1 can be explained as follows:

1. SO (Strengths-Opportunities) strategy is created by utilizing all available strengths to take advantage of all current opportunities.

2. The ST (Strengths-Threats) strategy utilizes the strengths that are owned to overcome threats.

3. The WO (Weakness-Opportunities) strategy takes advantage of existing opportunities by minimizing the weaknesses theyhave.

4. The WT (Weakness-Threats) strategy is defensive by minimizing weaknesses and avoiding existing threats.

\section{Result and Discussion}

Table 2 shows that the parking located in front of the Sami Laris shop is relatively dense compared to other parking locations. The Sami Laris Shop is the largest supermarket in the Klaten City shopping area, which is used as a shopping center that provides various items for daily needs. The average number of parking vehicles in the four parking locations sampled in an hour is 36 motorbikes if we pay attention. From the description of parking time shifts, it can be estimated that the number of motorbikes coming in using parking services for each shift in one day is shown in Table 3.

Meanwhile, for each parking lot location, 1-2 parking attendants are required in one shift, so that within one working day with two shifts, 2-4 parking attendants are required. It can be illustrated in Table 4. As shown in Table 3, the number of motorbikes parked for each plot is 432 units/day, assuming the number of motorbikes parked per hour is 36 units. Thus, it can be calculated that the number of motorbikes parked in the eleven plots of the four samples is $\mathbf{4 7 5 2}$ units. This description can be calculated using potential profit-sharing received by local governments, as shown in Table 5. 
Ristuningsih \& Hartarto

Analysis of Motorcycle Parking Charges in the Klaten City Shopping Area

Table 2 Parking Data for Shift I and Shift II Vehicles

\begin{tabular}{|c|c|c|c|c|c|}
\hline No. & Parking location & 2 Hours Shift I & 2 Hour Shift II & Total & Average / Hour \\
\hline \multirow[t]{4}{*}{1} & Best selling shop & & & & \\
\hline & - Lot I & 61 & 67 & 128 & 32 \\
\hline & - Lot II & 65 & 81 & 146 & 36.5 \\
\hline & - Lot III & 57 & 77 & 134 & 33.5 \\
\hline \multirow[t]{3}{*}{2} & Semar shop & & & & \\
\hline & - Lot I & 88 & 68 & 156 & 39 \\
\hline & - Lot II & 93 & 60 & 153 & 38.25 \\
\hline \multirow[t]{4}{*}{3} & Mas Semar shop & & & & \\
\hline & - Lot I & 67 & 48 & 115 & 28.75 \\
\hline & - Lot II & 64 & 46 & 110 & 27.5 \\
\hline & - Lot III & 63 & 55 & 118 & 29.5 \\
\hline \multirow[t]{4}{*}{4} & Sami's Shop Selling & & & & \\
\hline & - Lot I & 79 & 60 & 139 & 34.75 \\
\hline & - Lot II & 93 & 71 & 172 & 41 \\
\hline & - Lot III & 113 & 93 & 206 & 51.5 \\
\hline \multicolumn{2}{|c|}{ total } & & & & 392.25 \\
\hline \multicolumn{2}{|c|}{ Average } & & & & 36 \\
\hline
\end{tabular}

Sampling on Monday, January 9, 2017, 10.00-12.00 and 15.00-17.00

Table 3 Number of Vehicles / Plots

\begin{tabular}{ccccc}
\hline Shift & Punch & Total Time & $\begin{array}{c}\text { Number of Motorbikes / } \\
\text { Hour }\end{array}$ & Number of Motorbikes \\
\hline I & $08.00-14.00$ & 6 hours & 36 & 216 \\
II & $14.00-20.00$ & 6 hours & 36 & 216 \\
Total & & & & 432 \\
\hline
\end{tabular}

Table 4 Number of Parking Attendants

\begin{tabular}{|c|c|c|c|c|c|}
\hline Shift & Best selling shop & Semar shop & $\begin{array}{c}\text { Mas Semar } \\
\text { shop }\end{array}$ & $\begin{array}{l}\text { Sami's Shop } \\
\text { Selling }\end{array}$ & Total \\
\hline \multicolumn{6}{|l|}{ Shift I } \\
\hline - Lot I & 1 person & 1 person & 1 person & 2 persons & \\
\hline - Lot II & 1 person & 1 person & 1 person & 2 persons & 13 \\
\hline - Lot III & 1 person & - & 1 person & 1 person & people \\
\hline \multicolumn{6}{|l|}{ Shift II } \\
\hline - Chief I & 1 person & 1 person & 1 person & 1 person & \\
\hline - Lot II & 1 person & 1 person & 1 person & 1 person & 11 \\
\hline - Lot III & 1 person & - & 1 person & 1 person & people \\
\hline
\end{tabular}

Based on the Klaten Regent Regulation No. 26 of 2016 concerning Guidelines for Parking Lot Management, parking fee revenue sharing between local governments and parking managers is based on used tickets with a percentage of $55 \%$ for local governments and $45 \%$ for parking managers. Parking attendants are required to deposit a minimum of IDR 150,000 / shift, equivalent to 150 tickets. The rate charged to the public for each ticket is IDR 1,000. Table 5 shows that the potential revenue from motorcycle parking fees in the 
Klaten City shopping area is very profitable. This result is $14 \%$ of the total population of parking locations used as research objects in the shopping area of Klaten City.

Table 5 Potential Receipts of Vehicle Parking Charges by Local Gove rnments

\begin{tabular}{|c|c|c|c|c|c|}
\hline Parking location & $\begin{array}{c}\text { Number of } \\
\text { Vehicles / } \\
\text { Hour }\end{array}$ & $\begin{array}{l}\text { Number of } \\
\text { Vehicles / } \\
\text { Day }\end{array}$ & $\begin{array}{l}\text { Ticket } \\
\text { price }\end{array}$ & $\begin{array}{l}\text { Local } \\
\text { Government } \\
\text { Profit } \\
\text { Sharing (\%) }\end{array}$ & Total \\
\hline \multicolumn{6}{|l|}{ Best selling shop } \\
\hline - Lot I & 36 & 432 & IDR 1,000 & 55 & IDR 237,600 \\
\hline - Lot II & 36 & 432 & IDR 1,000 & 55 & IDR 237,600 \\
\hline - Lot III & 36 & 432 & IDR 1,000 & 55 & IDR 237,600 \\
\hline \multicolumn{6}{|l|}{ Semarshop } \\
\hline - Lot I & 36 & 432 & IDR 1,000 & 55 & IDR 237,600 \\
\hline - Lot II & 36 & 432 & IDR 1,000 & 55 & IDR 237,600 \\
\hline \multicolumn{6}{|l|}{ Mas Semar shop } \\
\hline - Lot I & 36 & 432 & IDR 1,000 & 55 & IDR 237,600 \\
\hline - Lot II & 36 & 432 & IDR 1,000 & 55 & IDR 237,600 \\
\hline - Lot III & 36 & 432 & IDR 1,000 & 55 & IDR 237,600 \\
\hline \multicolumn{6}{|l|}{ Sami's Shop Selling } \\
\hline - Lot I & 36 & 432 & IDR 1,000 & 55 & IDR 237,600 \\
\hline - Lot II & 36 & 432 & IDR 1,000 & 55 & IDR 237,600 \\
\hline - Lot III & 36 & 432 & IDR 1,000 & 55 & IDR 237,600 \\
\hline \multicolumn{5}{|c|}{ Number of days } & IDR 2,613,600 \\
\hline \multicolumn{5}{|c|}{ Amount / Month (30 days) } & IDR $78,408,000$ \\
\hline \multicolumn{5}{|c|}{ Amount/year (360 months) } & IDR $940,896,000$ \\
\hline
\end{tabular}

The amount of parking levy received from the four parking locations sampled is IDR $940,896,000$ with a $55 \%$ profit sharing on the total revenue at the parking location for one year with ticket price IDR 1,000 according to the regular rate applied in the Klaten City shopping area. The parking manager in each lot must deposit IDR 150,000 / shift, which means buying 150 parking tickets. Thus, the amount of revenue by the local government can be calculated as follows:

Table 6 Parking Charges received by LGs

\begin{tabular}{|c|c|c|c|c|c|c|}
\hline Shift & $\begin{array}{c}\text { Number of } \\
\text { Vehicles / } \\
\text { Plots }\end{array}$ & $\begin{array}{l}\text { Number of } \\
\text { Vehicles } \\
\text { for } 11 \text { Plots }\end{array}$ & Ticket price & $\begin{array}{c}\text { Profit- } \\
\text { sharing } \\
(\%)\end{array}$ & $\begin{array}{l}\text { Receipts / } \\
\text { Plots }\end{array}$ & $\begin{array}{c}\text { Admission for } 11 \\
\text { lots }\end{array}$ \\
\hline Shift I & 150 & 1650 & IDR 1,000 & 55 & IDR 82,500 & IDR 907,500 \\
\hline Shift II & 150 & 1650 & IDR 1,000 & 55 & IDR 82,500 & IDR 907,500 \\
\hline \multicolumn{6}{|c|}{ Number of days } & IDR 1,815,000 \\
\hline \multicolumn{6}{|c|}{ Admission/Month } & IDR 54,450,000 \\
\hline \multicolumn{6}{|c|}{ Acceptance // Year } & IDR $653,400,000$ \\
\hline
\end{tabular}

If the results of the calculation between the potential parking fees and the amount of parking fee received by the local government, the results can be seen as follows: 
Ristuningsih \& Hartarto

Analysis of Motorcycle Parking Charges in the Klaten City Shopping Area

Table 7 Potential Receipt of Parking Charges by the Local Government that are Missing

\begin{tabular}{llll}
\hline Time & $\begin{array}{c}\text { Potential Parking } \\
\text { Charges }\end{array}$ & $\begin{array}{r}\text { Acceptance of parking } \\
\text { fees by the local } \\
\text { government }\end{array}$ & $\begin{array}{c}\text { Missing Potential } \\
\text { for Acceptance }\end{array}$ \\
\hline Day & IDR $2,613,600$ & IDR $1,815,000$ & IDR 798,600 \\
Month & IDR $78,408,000$ & IDR $54,450,000$ & IDR $23,958,000$ \\
Year & IDR $940,896,000$ & IDR $653,400,000$ & IDR $287,496,000$ \\
\hline
\end{tabular}

From the comparison of the potential revenue for parking fees, it can be seen that the amount of revenue by the LG is still relatively low because the potential loss is still quite large. As the margin received by parking managers is IDR 450 from the regular rate of IDR 1,000 for each motorbike, so if each parking attendant shifts IDR 150,000, the total margin they receive is as follows.

Table 8 Margin received by Parking / Plots Management in One Day

\begin{tabular}{lccl}
\hline \multicolumn{1}{c}{ Shift } & Number of Vehicles / Shift & Margin / Unit & Total Margin \\
\hline Shift I & 216 & IDR 450 & IDR 97,200 \\
Shift II & 216 & IDR 450 & IDR 97,200 \\
Amount/lot & & & IDR 194,400 \\
Total 11 Plots & & & IDR 2.138.400 \\
\hline
\end{tabular}

The parking manager deposits IDR 150,000 worth 150 tickets to the local government. It can also imply that in one shift, the parking manager buys 150 tickets worth IDR 150,000. If a parking lot requires 1-2 parking attendants per shift with a wage of IDR 50,000 , then the parking manager's net profit can be found through the following calculations:

Table 9 Net Benefits of Parking Managers

\begin{tabular}{lllll}
\hline \multicolumn{1}{c}{ Shift } & $\begin{array}{c}\text { Parking Revenue } \\
\text { 11 Plots }\end{array}$ & $\begin{array}{c}\text { Parking attendant } \\
\text { wages 11 lots }\end{array}$ & $\begin{array}{c}\text { Ticket Cost for 11 } \\
\text { Plots }\end{array}$ & $\begin{array}{c}\text { Net Profits 11 } \\
\text { Plots }\end{array}$ \\
\hline I (13 people) & IDR 1,650,000 & IDR 650,000 & IDR 907,500 & IDR 92,500 \\
II (11 people) $\quad$ IDR 1,650,000 & IDR 550,000 & IDR 907,500 & IDR 192,500 \\
Net Profit 11 Plots / Day & & & IDR 285,000 \\
Net Profit 1 Lot / Day & & & IDR 26,000 \\
Net Profit 1Klot/Month & & & IDR 780,000 \\
Net Profit 1 Lot/Year & & & IDR 9,360,000 \\
\hline
\end{tabular}

The operational costs in parking management, as seen in Table 9, are one of the factors that support the high potential of parking locations, considering that parking attendants' wages and profit sharing for parking managers are relatively cheap. In this case, parking attendants' wages are no longer part of the local government's revenue-sharing but instead become part of the parking management revenue share. Suppose the four parking locations are assumed to represent $45 \%$ of the total population in the study in the Klaten City shopping area. In that case, the overall potential of the parking lots in the Klaten City shopping area can be calculated as follows: 
Table 10 Potential Charges for Parking for Shopping Areas in Klaten City

\begin{tabular}{lll}
\hline Time & Potential of the Four Sample Locations (45\%) & Potential Shopping Area (100\%) \\
\hline Day & IDR $2,613,600$ & IDR $5,808,000$ \\
Month & IDR $78,408,000$ & IDR $174,240,000$ \\
Year & IDR $940,896,000$ & IDR $2,090,880,000$ \\
\hline
\end{tabular}

Seeing the potential of the entire parking area used as the object of research can be calculated the total potential lost. With the local government revenue sharing of $55 \%$, the overall potential loss can be calculated as follows:

Table 11 Potential Receipts for Parking Retribution for Klaten City Shopping Areas by the Missing Local Government

\begin{tabular}{llll}
\hline \multicolumn{1}{|c}{ Time } & \multicolumn{1}{c}{$\begin{array}{c}\text { Potential Parking } \\
\text { Charges }\end{array}$} & $\begin{array}{c}\text { Acceptance of parking fees } \\
\text { by the local government }\end{array}$ & $\begin{array}{c}\text { Missing Potential for } \\
\text { Acceptance }\end{array}$ \\
\hline Day & IDR $5,808,000$ & IDR $3,194,400$ & IDR $2,613,600$ \\
Month & IDR $174,240,000$ & IDR $95,832,000$ & IDR $78,408,000$ \\
Year & IDR $2,090,880,000$ & IDR $1,149,984,000$ & IDR $940,896,000$ \\
\hline
\end{tabular}

The analysis of the Table 11 calculations shows that the potential for receiving lost parking fees is still quite enormous, especially if it is calculated within one year. The local govemment and the parties concemed can seek it through a new parking regulation to reduce the amount of potential loss. The parking manager does not only deposit a minimum parking fee of IDR 300,000 / day, which is equivalent to 300 tickets but a minimum of IDR 400,000 / day, which is equivalent to 400 tickets. This regulation will allow a reduction in the potential for lost parking fees so that revenue sharing by the local government increases as in the following calculation:

Table 12 Local Government Revenues through New Regulations

\begin{tabular}{lcccccc}
\hline $\begin{array}{l}\text { Shift } \\
\text { Nehicles / } \\
\text { Plots }\end{array}$ & $\begin{array}{c}\text { Number of } \\
\text { Vehicles for } \\
11 \text { Plots }\end{array}$ & $\begin{array}{c}\text { Ticket } \\
\text { price }\end{array}$ & $\begin{array}{c}\text { Profit- } \\
\text { sharing }\end{array}$ & $\begin{array}{c}\text { Reception / } \\
\text { Plots }\end{array}$ & Total Receipts for \\
11 Plots
\end{tabular}

The results of the local government's calculation of revenue sharing through the new regulation in Table 12 can be compared with the revenue sharing received by the local govemment before the regulation was issued. Thus, the reduction in potential loss can be estimated as follows:

Table 13 Reduction of Missing Potential

\begin{tabular}{llll}
\hline \multicolumn{1}{c}{ Time } & $\begin{array}{c}\text { Potential Parking } \\
\text { Charges }\end{array}$ & $\begin{array}{c}\text { Acceptance of Current } \\
\text { Parking Charges }\end{array}$ & $\begin{array}{r}\text { Acceptance of New } \\
\text { Parking Charges }\end{array}$ \\
\hline Day & IDR $2,613,600$ & IDR $1,815,000$ & IDR $2,420,000$ \\
Month & IDR $78,408,000$ & IDR $54,450,000$ & IDR $72,600,000$ \\
Year & IDR $940,896,000$ & IDR $653,400,000$ & IDR $871,200,000$ \\
\hline
\end{tabular}


The new regulation requires parking managers to deposit IDR 200,000 worth 200 tickets to the local government. If the parking attendant wages are fixed at IDR 50,000, then the parking manager's net profit after the new regulation can be found through the following calculations:

Table 14 Net Benefits of Parking Managers through New Regulations

\begin{tabular}{|lccl}
\hline \multicolumn{1}{|c}{$\begin{array}{c}\text { Shift } \\
\text { 11 Plots }\end{array}$} & $\begin{array}{c}\text { Parking } \\
\text { attendant wages } \\
11 \text { lots }\end{array}$ & $\begin{array}{c}\text { Ticket Cost for 11 } \\
\text { Plots }\end{array}$ & Net Profits 11 Plots \\
\hline I (13 people) $\quad$ IDR 2,200,000 & IDR 650,000 & IDR $1,210,000$ & IDR 340,000 \\
II (11 people) IDR 2,200,000 & IDR 550,000 & IDR $1,210,000$ & IDR 340,000 \\
Net Profit 11 Plots / Day & & & IDR 680,000 \\
Net Profit 1 Lot / Day & & & IDR 62,000 \\
Net Profit 1Kl ot / Month & & IDR $1,855,000$ \\
Net Profit 1 Lot / Year & & IDR $22,250,545$ \\
\hline
\end{tabular}

Through this new regulation, apart from making it possible to reduce the potential loss of parking fees to increase local government revenue, there is a consequence of a relatively high increase in the net income of parking managers. The minimum deposit amount is increased by IDR 200,000. However, the percentage of the profit-sharing between the parking manager and the local government is still 45:55 for the parking manager and the local government. Apart from the new regulation in Table 14, the local govemment may impose additional regulations and increase the deposit amount to IDR 200,000. PEMDA can increase the percentage of profit sharing to 65:35 for PEMDA and managers. It is expected to maximize LG revenue by reducing the potential for lost parking. The calculation of potential parking fees and profit-sharing with the new percentage can be seen as follows:

Table 15 Potential Receipt of Motorcycle Parking Levies by Local Governments with 65\% Profit Sharing

\begin{tabular}{|c|c|c|c|c|c|}
\hline Parking location & $\begin{array}{c}\text { Number of } \\
\text { vehicles/ } \\
\text { Hour }\end{array}$ & $\begin{array}{c}\text { Number of } \\
\text { Vehicles / } \\
\text { Day }\end{array}$ & $\begin{array}{l}\text { Ticket } \\
\text { price }\end{array}$ & $\begin{array}{l}\text { Local } \\
\text { Government } \\
\text { Profit Sharing }\end{array}$ & total \\
\hline \multicolumn{6}{|l|}{ Best selling shop } \\
\hline - Lot I & 36 & 432 & IDR 1,000 & $65 \%$ & IDR 280,000 \\
\hline - Lot II & 36 & 432 & IDR 1,000 & $65 \%$ & IDR 280,000 \\
\hline - Lot III & 36 & 432 & IDR 1,000 & $65 \%$ & IDR 280,000 \\
\hline \multicolumn{6}{|l|}{ SemarShop I } \\
\hline - Lot I & 36 & 432 & IDR 1,000 & $65 \%$ & IDR 280,000 \\
\hline - Lot II & 36 & 432 & IDR 1,000 & $65 \%$ & IDR 280,000 \\
\hline \multicolumn{6}{|l|}{ Semar Store II } \\
\hline - Lot I & 36 & 432 & IDR 1,000 & $65 \%$ & IDR 280,000 \\
\hline - Lot II & 36 & 432 & IDR 1,000 & $65 \%$ & IDR 280,000 \\
\hline - Lot III & 36 & 432 & IDR 1,000 & $65 \%$ & IDR 280,000 \\
\hline Sa mi's & & & & & \\
\hline Selling & 36 & 432 & IDR 1,000 & $65 \%$ & IDR 280,000 \\
\hline - Lot I & 36 & 432 & IDR 1,000 & $65 \%$ & IDR 280,000 \\
\hline - Lot II & 36 & 432 & IDR 1,000 & $65 \%$ & IDR 280,000 \\
\hline \multicolumn{6}{|l|}{ - Lot III } \\
\hline \multicolumn{3}{|l|}{ Number of days } & & & IDR 3,088,800 \\
\hline \multicolumn{3}{|c|}{ Amount / Month (30 days) } & & & IDR $92,664,000$ \\
\hline \multicolumn{3}{|c|}{ Amount/year (360 months) } & & & IDR 1,111,968,000 \\
\hline
\end{tabular}


Table 16 Net Profits for Parking Managers through New Regulations (Increase in Deposits and Change in Percentage for Profit Sharing)

\begin{tabular}{lcccc}
\hline Shift & $\begin{array}{c}\text { Parking Revenue } \\
\text { 11 Plots }\end{array}$ & $\begin{array}{c}\text { Staff Parking Fee } \\
\text { 11 Plots }\end{array}$ & $\begin{array}{c}\text { Ticket Cost for 11 } \\
\text { Plots }\end{array}$ & $\begin{array}{c}\text { Net Profits 11 } \\
\text { Plots }\end{array}$ \\
\hline I (13 people) $\quad$ IDR 2,200,000 & IDR 650,000 & IDR 1,430,000 & IDR 120,000 \\
II (11 people) $\quad$ IDR 2,200,000 & IDR 550,000 & IDR 1,430,000 & IDR 120,000 \\
Net Profit 11 Plots / Day & & & IDR 340,000 \\
Net Profit 1 Lot / Day & & & IDR 30,909 \\
Net Profit 1Klot/Month & & & IDR 927,273 \\
Net Profit 1 Lot/Year & & & IDR 11,127,273 \\
\hline
\end{tabular}

Table 17 Local Government Revenues through New Regulations (Increase in Deposits and Change in Percentage of Profit-Sharing)

\begin{tabular}{lcccccc}
\hline Shift & $\begin{array}{c}\text { Number of } \\
\text { Vehicles / } \\
\text { Plots }\end{array}$ & $\begin{array}{c}\text { Number of } \\
\text { Vehicles for } \\
11 \text { Plots }\end{array}$ & $\begin{array}{c}\text { Ticket } \\
\text { price }\end{array}$ & $\begin{array}{c}\text { Profit- } \\
\text { sharing }\end{array}$ & $\begin{array}{c}\text { Reception/ } \\
\text { Lot }\end{array}$ & $\begin{array}{c}\text { Total Receipts for } \\
11 \text { Plots }\end{array}$ \\
\hline I & 200 & 2200 & IDR 1,000 & $65 \%$ & IDR 130,000 & IDR $1,430,000$ \\
II & 200 & 2200 & IDR 1,000 & $65 \%$ & IDR 130,000 & IDR $1,430,000$ \\
Receipt/Day & & & & & IDR $2,860,000$ \\
Admission / Month & & & & & IDR $85,800,000$ \\
Admission/Year & & & & & IDR $1,029,600,000$ \\
\hline
\end{tabular}

Table 18 Reduced Potential Loss through New Regulations (Increase in Deposit and Change in Percentage of Profit-Sharing)

\begin{tabular}{llll}
\hline Time & Potential Parking Charges & \multicolumn{1}{c}{$\begin{array}{c}\text { Acceptance of Current } \\
\text { Parking Charges }\end{array}$} & $\begin{array}{c}\text { Acceptance of New } \\
\text { Parking Charges }\end{array}$ \\
\hline Day & IDR $3,088,800$ & IDR $1,815,000$ & IDR $2,860,000$ \\
Month & IDR $92,664,000$ & IDR $54,450,000$ & IDR $85,800,000$ \\
Year & IDR $1,111,968,000$ & IDR $653,400,000$ & IDR $1,029,600,000$ \\
\hline
\end{tabular}

Based on the Table 18, it can be seen that by using the new regulation by increasing the amount of the deposit to IDR 200,000 per shift and changing the percentage of profit sharing, namely 65:35 for the local government and parking managers, the amount of potentially lost parking can be reduced. It is very beneficial for the local government because it can increase the return on parking fees. Although the percentage of profit sharing received by parking managers has decreased to $35 \%$, parking managers still benefit because the net revenue from potential parking fees will increase.

On the other hand, the problems in parking locations are quite diverse. The trigger for the problem comes from two sides: the demand side (users of parking) and from the supply side (parking attendants/parking managers/PEMDA). One of the problems is related to users of parking services. It lacks knowledge and information about parking regulations causing users to receive modest services according to what parking attendants provide. Some users pay parking rates that exceed the regular rates due to users' low bargaining power and their ignorance of the actual amount of regular parking rates. Besides, users do not ask for tickets parking when the parking attendant did not deliver results in user ignorance of the actual parking rates.

Meanwhile, problems stemming from parking attendants usually arise due to the parking attendant's interests. Parking attendants want to get more income from the 


\section{Ristuningsih \& Hartarto \\ Analysis of Motorcycle Parking Charges in the Klaten City Shopping Area}

services they offer. They sometimes charge higher rates to some users of parking services. They do not even provide the tickets that are entitled to parking service users. It resulted in a reduction in the total tickets that should have been used.

Regarding parking management, the problems arising from the relationship between the manager and parking attendants. It is because the manager is responsible for the overall performance at the parking location. These problems include the lack of supervision of parking attendants' performance at parking locations due to the lack of parking supervisors. It has resulted in various misappropriations of parking attendants who work not according to regulations. Lack of education and training for parking attendants regarding performance also causes parking attendants to understand their responsibilities less. Inefficient use of local revenue is a significant factor in the lack of training activities for parking attendants.

Table 19 SWOT Matrix Analysis of Parking Charges for Shopping in Klaten City

\begin{tabular}{|c|c|c|}
\hline & Strengths (S) & Weakness (W) \\
\hline External Factors & $\begin{array}{l}\text { Shopping centers and various } \\
\text { other activities } \\
\text { Very potential to explorelocal } \\
\text { retribution }\end{array}$ & $\begin{array}{l}\text { Lack of parking attendant } \\
\text { supervision } \\
\text { Lack of counseling to the } \\
\text { public about parking } \\
\text { Lack of parking attendant } \\
\text { training and coaching }\end{array}$ \\
\hline Opportunities (O) & SO strategy & WO strategy \\
\hline $\begin{array}{l}\text { The population is increasing } \\
\text { The number of vehicles, } \\
\text { especially motorbikes, is } \\
\text { increasing every year } \\
\text { Become a transitarea for } \\
\text { motorists between } \\
\text { Surakarta City and } \\
\text { Yogyakarta Special Region }\end{array}$ & $\begin{array}{l}\text { Calculating the potential } \\
\text { parking fees regularly } \\
\text { Establishment of new parking } \\
\text { regulations } \\
\text { Set a minimum deposit } \\
\text { according to potential } \\
\text { Determine the ratio for the } \\
\text { results of retribution between } \\
\text { the local government and } \\
\text { parking managers according to } \\
\text { potential }\end{array}$ & $\begin{array}{l}\text { Additional parking } \\
\text { supervisors } \\
\text { Conducting education to the } \\
\text { community when there are } \\
\text { new regulations. Besides, } \\
\text { counseling regarding the } \\
\text { rights and obligations of } \\
\text { compulsory retribution } \\
\text { Routinely conduct coaching } \\
\text { and training to establish } \\
\text { parking attendant } \\
\text { responsibilities }\end{array}$ \\
\hline Threats $(\mathrm{T})$ & ST strategy & WT strategy \\
\hline $\begin{array}{l}\text { Clothing distributions began } \\
\text { to develop in various areas } \\
\text { in Klaten Regency } \\
\text { Supermarkets began to } \\
\text { spread in various regions }\end{array}$ & $\begin{array}{l}\text { The development of a } \\
\text { shopping area becomes a } \\
\text { shopping center that is more } \\
\text { attractive to the community }\end{array}$ & $\begin{array}{l}\text { Manage and improve the } \\
\text { Klaten City shopping area } \\
\text { Mapping of locations in the } \\
\text { Klaten City shopping area } \\
\text { regarding its potential }\end{array}$ \\
\hline
\end{tabular}

All these problems have led to ineffective parking performance. The local government's lack of information and education, both to parking attendants and the public, has caused parking conditions never to finish. Passive consumers who are less knowledgeable and have low bargaining power will lead to a lack of indirect control over the supervision of parking attendants from the community. Deviations made by parking attendants lead to irregularities in parking revenue so that the larger the parking location, the greater the income is diverted. All of these obstacles will ultimately impact 
the loss of potential revenue from parking fees so that it can reduce regional income from its true potential. The low regional income then becomes the reason for the local govemment not to provide various counseling and education to parking attendants and the community because of regional spending efficiency. From the existing problems, a strategy can be formulated using SWOT analysis techniques to manage parking in the Klaten City shopping area to make it more effective and efficient, as shown in Table 19.

Based on these findings, several other studies have also suggested the same thing. Sumardianto (2020) concluded that parking levy revenue in other cities such as ParePare City is not optimal. It is due to poor management of existing parking lots. Besides, govemment regulations have contributed to the inefficient utilization of the potential parking fees. As in Jember Regency (Haerah, 2018), this problem has made parking fees in Jember Regency decrease every year.

\section{Conclusion}

Parking fees are one of the potential sources of PAD in Klaten City from year to year. However, so far, the Klaten Regional Government has not carried out optimal management, so that there are still many potentials that are lost from the overall potential. The amount of potential revenue from the Klaten local government per year is currently only IDR 59,400,000.00, while the local government's amount of potential revenue has lost parking fee is IDR $48,600,000.00$. This revenue is minimal when viewed from the potential calculated based on the number of parked vehicles so that the Klaten Government's acceptance cannot be said optimally. The parking manager only pays IDR 150,000 / shift, which is the equivalent of 150 vehicles, whereas, during one shift, the number of vehicles using parking services can reach 216 vehicles.

To optimize parking levies, the Klaten Regional Government, through the Klaten District Parking and Terminal Technical Implementation Unit, has supervised parking fee collection and held regular meetings to provide information and training to parking managers' parking attendants. However, the Klaten Regional Government's current efforts are not yet optimal because there are still many parking attendants who work not according to regulations. The right strategy to optimize parking fees' potential can be implemented by imposing new regulations, namely increasing the deposit amount to IDR 200,000 per shift and changing the profit-sharing ratio to $65 \%$ for local governments and $35 \%$ for parking managers. With this regulation, the local govemment's potential receipt of parking fees may increase to IDR $93,600,000$ of all its true potential.

\section{References}

Arsyad, L. (1999). Pengantar perencanaan dan pembangunan ekonomi daerah. Yogyakarta: BPFE Butarbutar, TE 2014. Analisa peranan pajak parkir terhadap peningkatan pendapatan asli daerah di kota Tomohon. Jurnal Emba: Jurnal Riset Ekonomi, Manajemen, Bisnis dan 
Akuntansi, 2(4), 697-704. Retrieved from https:// ejournal.unsrat.ac.id/index.php/emba/article/view/ 6440

Haerah, K. (2018). Kontribusi penerimaan retribusi parkir terhadap pendapatan asli daerah kabupaten Jember. Politico, 18(1). 80-122.

Kesek, F. (2013). Efektivitas dan kontribusi penerimaan pajak parkir terhadap pendapatan asli daerah kota Manado. Jurnal Riset Ekonomi Manajemen Bisnis dan Akuntansi, 1(4), 1922-1933. Retrieved from https:// ejournal.unsrat.ac.id/index.php/emba/article/view/3400

Purnamasari, I., \& Ngumar, S. (2015). Pelaksanaan retribusi parkir dalam meningkatkan pendapatan asli daerah di kota Surabaya. Jurnal Ilmu dan Riset Akuntansi, 4(10), 1-21. Retrieved from http://jurnalmahasiswa.stiesia.ac.id/index.php/jira/article/view/3223

Putri, R.W. (2016). Analisis kontribusi parkir terhadap pendapatan asli daerah kabupaten Malang. Jurnal Ekonomi dan Studi Pembangunan, 8(1), 23-32. Retrieved from http://journal.um.ac.id/index.php/jesp/article/view/5286

Sumardianto. (2020). Analisis kontribusi retribusi parkir terhadap pendapatan asli daerah (PAD) di kota Pare-Pare. Decision, 1(2), 129-134. Retrieved from https://jurnal.umpar.ac.id/index.php/decision/article/view/602 